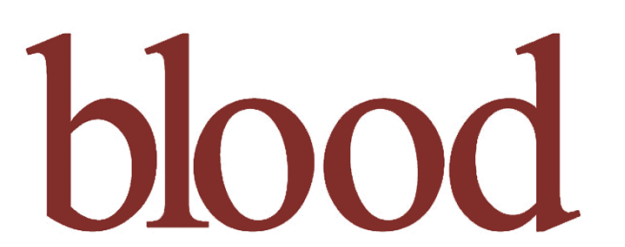

2004 103: 3230-3232

Prepublished online Dec 30, 2003;

doi:10.1182/blood-2003-06-1985

\title{
Lack of effect of the human GM-CSF analog E21R on the survival of primary human acute myeloid leukemia cells
}

Ira Jakupovic, Victoria L. Grandage, David C. Linch and Asim Khwaja

Updated information and services can be found at:

http://bloodjournal.hematologylibrary.org/cgi/content/full/103/8/3230

Articles on similar topics may be found in the following Blood collections:

Apoptosis (747 articles)

Brief Reports (1057 articles)

Neoplasia (4075 articles)

Information about reproducing this article in parts or in its entirety may be found online at:

http://bloodjournal.hematologylibrary.org/misc/rights.dtl\#repub_requests

Information about ordering reprints may be found online at:

http://bloodjournal.hematologylibrary.org/misc/rights.dt|\#reprints

Information about subscriptions and ASH membership may be found online at:

http://bloodjournal.hematologylibrary.org/subscriptions/index.dtl

Blood (print ISSN 0006-4971, online ISSN 1528-0020), is published

semimonthly by the American Society of Hematology, 1900 M St, NW, Suite 200, Washington DC 20036.

Copyright 2007 by The American Society of Hematology; all rights reserved.

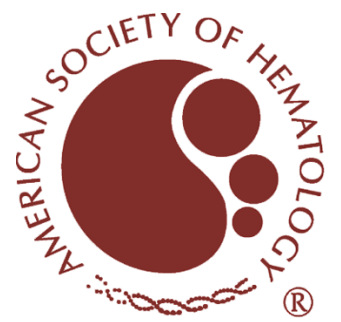




\title{
Brief report
}

\section{Lack of effect of the human GM-CSF analog E21R on the survival of primary human acute myeloid leukemia cells}

\author{
Ira Jakupovic, Victoria L. Grandage, David C. Linch, and Asim Khwaja
}

The granulocyte-macrophage colonystimulating factor (GM-CSF) analog E21R binds to the GM-CSF receptor complex with low affinity and acts as a competitive antagonist. In addition, it has been reported to be a potent direct activator of apoptosis in primary human acute myeloid leukemia (AML) cells. We have confirmed the ability of E21R to neutralize the

\author{
biologic effects of GM-CSF and investi- \\ gated its activity on primary AML blasts. \\ We find that it failed to induce cell death \\ in blast cells from 23 separate AML cases \\ treated in vitro at concentrations of E21R \\ up to $30 \mu \mathrm{g} / \mathrm{mL}$. Significant cell death \\ resulted in all cases after incubation with \\ cytosine arabinoside. The lack of effect of \\ E21R on AML blasts was unlikely to be
}

due to an absence of functional GM-CSF receptors because 13 cases demonstrated an increase in cell number with the addition of exogenous GM-CSF. These results do not support the use of E21R for the treatment of AML. (Blood. 2004;103: 3230-3232)

๑) 2004 by The American Society of Hematology

\section{Introduction}

Granulocyte-macrophage colony-stimulating factor (GM-CSF) promotes the survival, proliferation, and activation of cells ranging from myeloid progenitors to terminally differentiated neutrophils. ${ }^{1}$ The effects of GM-CSF are mediated via high-affinity binding to heterodimeric cell surface receptors consisting of a GM-CSFspecific $\alpha$ chain and a $\beta$ chain that is shared with the receptors for interleukin-3 (IL-3) and IL-5.,3 Binding of GM-CSF to the $\alpha$ chain alone is of low affinity. ${ }^{4}$ The glutamate residue at position 21 of GM-CSF is involved in GM-CSF binding to both chains of the $\alpha \beta$ complex; its substitution by arginine (GM-CSF E21R) results in a molecule capable of binding with low affinity to the $\alpha$ chain but with no high-affinity binding to the $\alpha \beta$ complex. ${ }^{5}$ E21R functions as a competitive antagonist of GM-CSF binding to the $\alpha \beta$ complex and can neutralize its biologic effects. ${ }^{6}$

In addition to its neutralizing activity, E21R is reported to directly induce apoptosis in cells expressing high-affinity GM-CSF receptors even in the absence of exogenous GM-CSF. Cells reported to undergo apoptosis include normal hemopoietic progenitors, ${ }^{7}$ primary acute myeloid leukemia (AML) blasts, ${ }^{7}$ eosinophils, ${ }^{8}$ and the Jurkat T-cell line engineered to express the high-affinity GM-CSF receptor. ${ }^{9}$ This potent proapoptotic effect was shown to be an active process requiring protein kinase activity, the synthesis of new proteins, ${ }^{7}$ and the membrane proximal portion of the intracytoplasmic domain of the common $\beta$ chain to be present. ${ }^{9}$ Caspase inhibitors were shown to block the effects of E21R, whereas overexpression of Bcl-2 was ineffective. ${ }^{9} \mathrm{E} 21 \mathrm{R}$ has also been shown to have biologic effects against the survival and proliferation of juvenile myelomonocytic leukemic (JMML) cells in vitro ${ }^{10}$ and in vivo ${ }^{11}$ and has anti-chronic myelomonocytic leukemia (anti-CMML) activity demonstrated by inhibition of spontaneous colony formation in vitro. ${ }^{12}$
Functional GM-CSF receptors are found on the blast cells of most patients with AML, ${ }^{13-15}$ and exogenously added recombinant GM-CSF can stimulate proliferation of AML cells. ${ }^{16-21}$ There is evidence that autocrine production of GM-CSF may play a part in leukemia cell proliferation. ${ }^{22,23}$ The profound proapoptotic effects of E21R in all 21 cases of primary AML previously reported raised the possibility that E21R may be very useful in the treatment of AML and prompted us to investigate its effects on AML cell survival and proliferation.

\section{Study design}

Blasts were isolated from the peripheral blood or bone marrow of patients with newly diagnosed AML by standard Ficoll-Hypaque separation. Informed consent was obtained according to the Joint University College London/University College London Hospitals Ethics Committee guidelines. Samples were either used fresh or after recovery from liquid nitrogen. A total of 21 of 23 samples were thawed and incubated in RPMI/10\% fetal calf serum (FCS) at $37^{\circ} \mathrm{C} / 5 \% \mathrm{CO}_{2}$ and underwent a further Ficoll separation to remove dead cells where necessary. Samples were incubated with varying concentrations of E21R (BresaGen, British Biotech, Oxford, United Kingdom), GM-CSF (Hoechst-Behringwerke, Marburg, Germany) (or both), or cytosine arabinoside (Sigma, St Louis, MO) at a cell density of $0.5 \times 10^{6} / \mathrm{mL}$ to $1 \times 10^{6} / \mathrm{mL}$ in RPMI $/ 10 \%$ FCS for up to 72 hours. Cell proliferation was measured using an MTS (3-(4,5 dimethylthiazol-2-yl)-5(3-carboxymethoxyphenyl-2-(4-sulfophenyl)-2H-tetrazolium) assay (CellTiter 96, Promega, Madison, WI). The assay was performed according to manufacturer's instructions, and the results are expressed as a percentage of the absorbance reading obtained with cells incubated in RPMI/10\% FCS alone. Apoptosis was measured by annexin V binding as previously described. ${ }^{24}$
From the Department of Haematology, Royal Free \& University College Medical School, London, United Kingdom.

Submitted June 19, 2003; accepted December 19, 2003. Prepublished online as Blood First Edition Paper, December 30, 2003; DOI 10.1182/blood-2003-061985.

Supported by British Biotech (I.J.), the Kay Kendall Leukaemia Fund (V.L.G.), and the Medical Research Council, United Kingdom (A.K.).
Reprints: Asim Khwaja, Department of Haematology, Royal Free \& University College Medical School, 98 Chenies Mews, London WC1E 6HX, United Kingdom; e-mail: a.khwaja@ucl.ac.uk.

The publication costs of this article were defrayed in part by page charge payment. Therefore, and solely to indicate this fact, this article is hereby marked "advertisement" in accordance with 18 U.S.C. section 1734.

(c) 2004 by The American Society of Hematology 
Figure 1. Effects of E21R and cytosine arabinoside. (A) Effect of E21R or cytosine arabinoside (Ara-c) on the survival of AML blasts. Primary AML blasts were incubated with increasing concentrations of E21R for the indicated times or with increasing concentrations of cytosine arabinoside for 48 hours. Samples were assayed in duplicate by the MTS technique for viable cell number, and the data are presented as the mean \pm SEM activity as a percentage of the result obtained with cells incubated without additives. For E21R, $\mathrm{n}=15$ at 24 hours ( $\square$ ), 23 at 48 hours (圆), and 14 at 72 hours ( $\square$ ). For Ara-c, $\mathrm{n}=21$ at 48 hours (四). (B) Effect of E21R combined with Ara-c on the survival of AML blasts. Primary AML blasts were incubated with Ara-c alone (at $10 \mathrm{ng} / \mathrm{mL}$ or $100 \mathrm{ng} / \mathrm{mL}$ ) or in combination with E21R (10 $\mu \mathrm{g} / \mathrm{mL}$ ) for 48 hours and cell survival measured by MTS assay (mean \pm SEM of 21 samples)

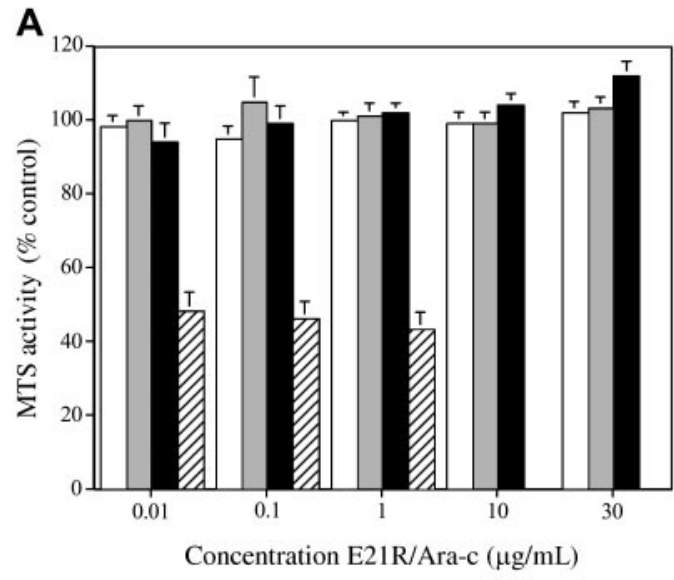

B

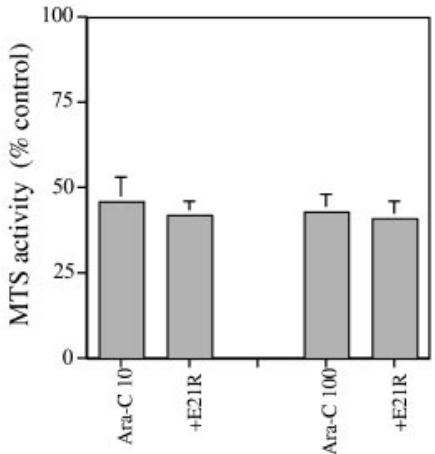

\section{Results and discussion}

Increasing concentrations of E21R were incubated with primary blast cells from a total of 23 patients with AML. After 48 hours, surviving cells were quantified using an MTS-based assay. Figure 1 shows that there was no reduction in cell number at 48 hours at any concentration of E21R up to a maximum of $30 \mu \mathrm{g} / \mathrm{mL}$. Flow cytometric assays for annexin $\mathrm{V}$ binding carried out at 48 hours in a subset of 10 patients also failed to show an increase in apoptosis in the presence of E21R (control, $45 \% \pm 6 \%$ annexin-positive; E21R $10 \mu \mathrm{g} / \mathrm{mL}, 46 \% \pm 6 \%$ positive).

Because of these unexpected findings, prolonged incubation for 72 hours was carried out in 14 patient samples. Again, no decrease in cell survival was detected. In addition to its lack of effect on primary AML blasts, E21R failed to induce apoptosis in HL-60 and U937 cell lines, both of which express high-affinity GM-CSF receptors. ${ }^{25}$ E21R did not affect the survival of TF-1 cells cultured in erythropoietin (Figure 2), MO7e cells cultured in stem cell factor (SCF) or thrombopoietin (data not shown), or primary human CD34 ${ }^{+}$-derived cells cultured in G-CSF (Figure 2).

To confirm that the assay systems were effective at detecting cell death, we incubated AML blasts with cytosine arabinoside.
This effectively reduced viable cell numbers by 48 hours as detected by the MTS assay to $48 \% \pm 5 \%$ (range, $9 \%$ to $91 \%$ ) of control (Figure $1 ; \mathrm{n}=21$ ) and led to a significant increase in the number of annexin-binding cells from $45 \% \pm 6 \%$ to $76 \% \pm 6 \%$ $(\mathrm{n}=10)$. The absence of any effect of E21R could be due to a lack of GM-CSF receptors on AML blasts. However, previous publications have shown that blast cells from most AML patients express the GM-CSF receptor, ${ }^{13-15}$ and we have previously demonstrated the presence of GM-CSF receptors on AML blasts in all 3 patients investigated using ${ }^{125} \mathrm{I}-\mathrm{GM}-\mathrm{CSF}$ with a mean of $107 \pm 28$ highaffinity binding sites (dissociation constant $\left[\mathrm{K}_{\mathrm{D}}\right], 64 \pm 10 \mathrm{pM}$ ) and $2684 \pm 1511$ low-affinity sites $\left(K_{D}, 5.6 \pm 3.7 \mathrm{nM}\right)$ per cell (A.K. and D.C.L., unpublished data, July 1993). We found that 13 of 23 patients studied here had a clear response to increasing concentrations of GM-CSF with a significant increase in MTS activity at 48 to 72 hours (Figure 2). These data are in keeping with those published by others showing GM-CSF responsiveness in primary AML blasts. ${ }^{16-21}$ In addition to investigating the effects of E21R as a single agent, we have combined it with cytosine arabinoside and did not find any evidence of synergy (Figure 1).

To confirm that the E21R used was biologically active, we used it as a competitive antagonist of GM-CSF. Figure 2 shows
A

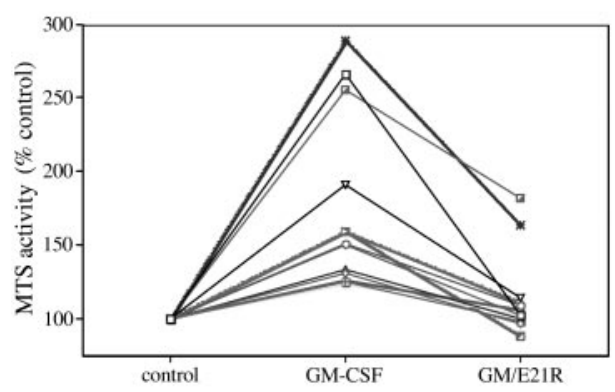

B

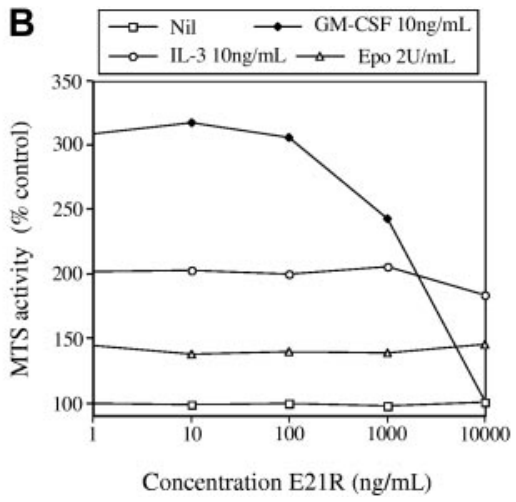

C

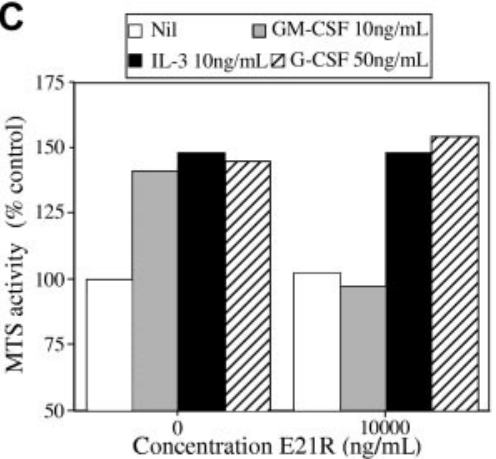

Figure 2. Neutralization of GM-CSF by E21R. (A) Response of AML blasts to exogenous GM-CSF and its neutralization by E21R. Primary AML blasts from 13 individuals showing a response to exogenous GM-CSF. Cells were incubated in medium plus GM-CSF at $10 \mathrm{ng} / \mathrm{mL}$ for 48 to 72 hours either without or with an at least 1000 -fold excess of $\mathrm{E} 21 \mathrm{R}(10$ to $30 \mu \mathrm{g} / \mathrm{mL})$. MTS assay was carried out, and the results are expressed as a percentage of the activity in control cells incubated in medium alone. (B) Effect of E21R in neutralizing the proliferative response of TF-1 cells to GM-CSF. TF-1 cells were washed and placed in medium alone, GM-CSF (10 ng/mL), IL-3 (10 ng/mL), or erythropoietin $(2 \mathrm{U} / \mathrm{mL})$ with the indicated concentrations of E21R for 48 hours. MTS assay was carried out, and the results are expressed as a percentage of the activity in control cells incubated in medium alone. (C) Effect of E21R in neutralizing the proliferative response of normal myeloid cells to GM-CSF. Primary CD34 ${ }^{+}$cells were placed in medium with SCF, IL-3, and G-CSF for 7 days to induce myeloid differentiation. After washing, cells were incubated for 48 hours in medium alone or with GM-CSF (10 ng/mL), IL-3 (10 $\mathrm{ng} / \mathrm{mL})$, or G-CSF $(50 \mathrm{ng} / \mathrm{mL})$ without or with E21R $(10 \mu \mathrm{g} / \mathrm{mL})$. MTS assay was carried out, and the results are expressed as a percentage of the activity in control cells incubated in medium alone. 
that E21R neutralizes the effect of human GM-CSF in stimulating the survival and proliferation of the factor-dependent cell line TF- 1 and of myeloid cells in a primary CD $34^{+}$cell-derived liquid culture. In addition, Figure 2 shows that in primary AML blasts from patients who showed a response to GM-CSF in the MTS assay, this could be neutralized by the addition of an excess of E21R.

In summary, we found that the GM-CSF antagonist E21R does not have antileukemic activity in primary AML blasts obtained from 23 patients. This lack of effect was unlikely to be due to an absence of high-affinity GM-CSF receptors, because 13 of 23 cases had a clear survival response to exogenous GM-CSF. The reason for the difference between our findings and those of Iversen et al is not clear. We used concentrations of E21R up to 30-fold higher than those previously shown to induce death of more than 95\% of AML blasts from 21 patients. ${ }^{7}$ These blasts had been selected using an anti-GM-CSF receptor $\alpha$ antibody and magnetic beads and represented $50 \%$ to $75 \%$ of the total blast population. It is possible that this process could influence cell survival. However, Iversen et $\mathrm{al}^{7}$ also found that unselected AML blasts underwent apoptosis in response to E21R and that the proportion of cells apoptotic at 48 hours correlated completely with the number of cells expressing GM-CSF receptor $\alpha$ (ranging up to 75\%). We did not find any reduction in viable cells using either the MTS technique or annexin V binding in response to E21R, whereas clear effects of cytosine arabinoside were detected. The E21R used in our experiments was biologically active in neutralizing the effects of exogenous GM-CSF. In conclusion, these studies do not support the use of E21R for the treatment of AML.

\section{References}

1. Bagby GC, Heinrich MC. Growth factors, cytokines, and the control of hematopoiesis. In: Hoffman R, Benz EJ, Shattil SJ, et al, eds. Hematology: Basic Principles and Practice. 3rd ed. New York, NY: Churchill Livingstone; 2000:154-201.

2. Nicola NA, Metcalf D. Subunit promiscuity among hemopoietic growth factor receptors. Cell. 1991; 67:1-4.

3. Hoang T, De Lean A, Haman A, Beauchemin V, Kitamura T, Clark SC. The structure and dynamics of the granulocyte macrophage colony-stimulating factor receptor defined by the ternary complex model. J Biol Chem. 1993;268:11881-11887.

4. Gearing DP, King JA, Gough NM, Nicola NA. Expression cloning of a receptor for human granulocyte-macrophage colony-stimulating factor. EMBO J. 1989;8:3667-3676.

5. Lopez AF, Shannon MF, Hercus T, et al. Residue 21 of human granulocyte-macrophage colonystimulating factor is critical for biological activity and for high but not low affinity binding. EMBO J. 1992;11:909-916.

6. Hercus TR, Bagley CJ, Cambareri B, et al. Specific human granulocyte-macrophage colonystimulating factor antagonists. Proc Natl Acad Sci U S A. 1994;91:5838-5842.

7. Iversen PO, To LB, Lopez AF. Apoptosis of hemopoietic cells by the human granulocyte-macrophage colony-stimulating factor mutant E21R. Proc Natl Acad Sci U S A. 1996;93:2785-2789.

8. Iversen PO, Robinson D, Ying S, et al. The GMCSF analogue E21R induces apoptosis of normal and activated eosinophils. Am J Respir Crit Care Med. 1997;156:1628-1632.

9. Iversen PO, Hercus TR, Zacharakis B, et al. The apoptosis-inducing granulocyte-macrophage colony-stimulating factor (GM-CSF) analog E21R functions through specific regions of the heterodimeric GM-CSF receptor and requires interleukin-1beta-converting enzyme-like proteases. J Biol Chem. 1997;272:9877-9883.
10. Iversen PO, Rodwell RL, Pitcher L, Taylor KM, Lopez AF. Inhibition of proliferation and induction of apoptosis in juvenile myelomonocytic leukemic cells by the granulocyte-macrophage colonystimulating factor analogue E21R. Blood. 1996; 88:2634-2639.

11. Iversen PO, Lewis ID, Turczynowicz S, et al. Inhibition of granulocyte-macrophage colony-stimulating factor prevents dissemination and induces remission of juvenile myelomonocytic leukemia in engrafted immunodeficient mice. Blood. 1997;90: 4910-4917.

12. Ramshaw HS, Bardy PG, Lee MA, Lopez AF. Chronic myelomonocytic leukemia requires granulocyte-macrophage colony-stimulating factor for growth in vitro and in vivo. Exp Hematol. 2002;30:1124-1131.

13. Kelleher CA, Wong GG, Clark SC, Schendel PF, Minden MD, McCulloch EA. Binding of iodinated recombinant human GM-CSF to the blast cells of acute myeloblastic leukemia. Leukemia. 1988;2: 211-215.

14. Budel LM, Touw IP, Delwel R, Clark SC, Lowenberg B. Interleukin-3 and granulocyte-monocyte colony-stimulating factor receptors on human acute myelocytic leukemia cells and relationship to the proliferative response. Blood. 1989;74:565571.

15. Onetto-Pothier N, Aumont N, Haman A, et al. Characterization of granulocyte-macrophage colony-stimulating factor receptor on the blast cells of acute myeloblastic leukemia. Blood. 1990;75:59-66.

16. Griffin JD, Young D, Herrmann F, Wiper D, Wagner K, Sabbath KD. Effects of recombinant human GM-CSF on proliferation of clonogenic cells in acute myeloblastic leukemia. Blood. 1986;67: 1448-1453.

17. Vellenga E, Ostapovicz D, O'Rourke B, Griffin JD. Effects of recombinant IL-3, GM-CSF, and G-CSF on proliferation of leukemic clonogenic cells in short-term and long-term cultures. Leukemia. 1987:1:584-589.

18. Delwel R, Salem M, Pellens C, et al. Growth regulation of human acute myeloid leukemia: effects of five recombinant hematopoietic factors in a serum-free culture system. Blood. 1988;72: 1944-1949.

19. Lista P, Brizzi MF, Avanzi G, Veglia F, Resegotti L, Pegoraro L. Induction of proliferation of acute myeloblastic leukemia (AML) cells with hemopoietic growth factors. Leuk Res. 1988;12:441-447.

20. Tsao CJ, Cheng TY, Chang SL, Su WJ, Tseng JY. Effects of granulocyte-macrophage colony-stimulating factor and interleukin 6 on the growth of leukemic blasts in suspension culture. Int J Cell Cloning. 1992;10:166-172

21. Estrov Z, Estey EH, Andreeff M, et al. Comparison of in vivo and in vitro effects of granulocytemacrophage colony-stimulating factor (GM-CSF) in patients with acute myeloid leukemia. Exp Hematol. 1992;20:558-564

22. Young DC, Griffin JD. Autocrine secretion of GM CSF in acute myeloblastic leukemia. Blood. 1986; 68:1178-1181.

23. Reilly IA, Kozlowski R, Russell NH. Heterogeneous mechanisms of autocrine growth of AML blasts. Br J Haematol. 1989;72:363-369.

24. Somervaille TC, Linch DC, Khwaja A. Growth factor withdrawal from primary human erythroid progenitors induces apoptosis through a pathway involving glycogen synthase kinase- 3 and Bax. Blood. 2001;98:1374-1381.

25. Roberts PJ, Khwaja A, Lie AK, et al. Differentiation-linked changes in tyrosine phosphorylation, functional activity, and gene expression downstream from the granulocyte-macrophage colonystimulating factor receptor. Blood. 1994;84:10641073. 